\title{
Pendugaan Kejadian Pemutihan Karang Berdasarkan Analisis Suhu Permukaan Laut (SPL) Tahun 2015-2016 di Perairan Bali
}

\author{
Jajang Nuryana a*, I Gede Hendrawan a, Widiastuti ${ }^{\text {a }}$ \\ a Program Studi Ilmu Kelautan, Fakultas Kelautan dan Perikanan, Universitas Udayana, Kampus UNUD Bukit Jimbaran, Bali 80361, \\ Indonesia \\ *Penulis koresponden. Tel.: +6285-238-166-292 \\ Alamat e-mail: nuryanahusen.jajang@asia.com
}

Diterima (received) 15 Juni 2017; disetujui (accepted) 7 November 2017; tersedia secara online (available online) 8 November 2017

\begin{abstract}
National Ocean Atmospheric Administrations (NOAA) by the program coral reef Watch (CRW) has developed a method to estimate the potential of coral bleaching using Sea Surface Temperature (SST). The products are hot spot (HS) and degree heating week (DHW). HS is the SST $1^{\circ} \mathrm{C}(\mathrm{SSTL} \geq 1)$ above normal and DHW is the length of HS inhabits a place. The CRW product do not provided detail informations because it has a lower resolution. It is need a satellite image with a higher resolution to provide better informations. One of the satellite images that can be used is Moderate Resolution Imaging Spectroradiometer (MODIS) with a spatial resolution of $1 \mathrm{~km}$. The purpose of this study was to know HS and DHW distribution patterns and status of coral bleaching in Bali waters seen from the analysis of HS and DHW. MODIS data is used daily, then do mosaicing process to get a weekly SPL (8 daily) and the monthly SST. Monthly SPL normally used to get maximum montly mean (MMM). HS obtained from the difference between 8 daily weekly SST and SST normal (MMM).).Location bleaching based on data Coral Triangle Center (CTC) and coralwatch.org. SST results revealed difference of SPL in 2015 and 2016 amounted to $1.48^{\circ} \mathrm{C}$. Highest DHW in Bali Hai, Nusa Penida is $10465^{\circ}$ C-weeks in April 2016. Based on the value HS and DHW coral reefs in Bali waters threatened bleaching level Alert 1 and Alert level 2.
\end{abstract}

Keywords: coral bleaching; hotspot; dhw; sst.

\begin{abstract}
Abstrak
National Ocean Atmospheric Administrations (NOAA) melalui program Coralreef Watch (CRW) mengembangkan metode untuk mengestimasi potensi pemutihan karang menggunakan Suhu Permukaan Laut (SPL). Produk yang dihasilkan adalahHotspot (HS) dan Degree heating Week (DHW).HS adalah SPL diatas $1^{\circ} \mathrm{C}(\mathrm{SPL} \geq 1)$ diatas kondisi normal dan DHW adalah lama tinggal HS.Produk HS dan DHW CRW kurang memberikan infomasi secara rinci karena memiliki resolusi yang rendah.Oleh karena itu diperlukan citra satelit dengan resolusi yang lebih tinggi untuk memberikan informasi yang lebih baik. Salah satu citra satelit yang dapat digunakan adalah Moderate Resolution Imaging Spectroradiometer (MODIS) dengan resolusi spasial $1 \mathrm{~km}$. Tujuan penelitian ini adalah untukmengetahui pola distribusi HS dan DHW di Perairan pulau Bali dan mengatahui status pemutihan karang dilihat dari analisa HS dan DHW. Data MODIS yang digunakan adalah harian, kemudian dilakukan proses mosaicking untuk mendapatkan SPL mingguan (8 harian) dan SPL bulanan. Pengolahan data SPL tahun 2015-2016 dilakukan untuk mendapatkan kondisi normal (MMM).HS didapatkan dari selisih SPL mingguan 8 harian dengan SPL bulanan tertinggi (MMM) .HS digunakan untuk menghitung degree heating week (DHW $\left({ }^{\circ} \mathrm{C}\right.$-minggu).Lokasi pemutihan karang berdasarkan data Coral Triangle Center (CTC) dan coralwatch.org.Hasil pengolahan SPL menunjukan terdapat selisih rata-rata SPL tahun 2015 dan 2016 sebesar $1.48^{\circ} \mathrm{C}$. Pengukuran DHW menunjukan DHW tertinggi di perairan Bali Hai, Nusa Penida yaitu $10.465^{\circ} \mathrm{C}$-minggu pada bulan April 2016. Berdasarkan nilai HS dan DHW terumbu karang di perairan Bali terancam dengan level pemutihan level Alert 1 dan Alert 2.
\end{abstract}

Kata Kunci: coral bleaching; hotspot; degree heating weeks; sst. 


\section{Pendahuluan}

Terumbu karang merupakan salah satu ekosistem laut dengan produktifitas yang sebanding dengan hutan hujan tropis (Eakin et al., 2010). Keanekaragaman hayati ekosistem ini memberikan kontribusi yang besar terhadap sektor perikanan dan (Burke et al., 2012). Secara langsung, ekosistem terumbu karang berfungsi sebagai penyedia bahan makanan dan obat-obatan bagi kehidupan manusia. Sedangkan secara ekologi, ekosistem terumbu karang berfungsi sebagai penopang ekosistem - ekosistem lain disekitarnya, seperti ekosistem lamun dan ekosistem mangrove (Yudasmara, 2015).

Kelangsungan hidup karang sebagai organisme pembentuk terumbu dibatasi oleh beberapa faktor, diantaranya faktor lingkungan seperti suhu permukaan laut (SPL). Kondisi lingkungan perairan sangat dipengaruhi oleh iklim global. Peningkatan suhu permukaan laut (SPL) rata-rata global disebabkan oleh fenomena global warming. SPL yang tinggi menyebabkan pemutihan karang. Pemutihan karang telah menjadi salah satu faktor paling signifikan dalam degradasi terumbu karang (Wilkinson, 2008).

Kenaikan SPL diatas kondisi normal dapat menghambat bahkan merusak proses fotosintesis mikroalga simbiotik (zooxanthellae) yang hidup di jaringan karang sehingga menyebabkan berkurangnya kepadatan sel atau kematian zooxanthellae. Dengan demikian karang kehilangan pigmen warna sehingga meninggalkan warna putih pada kerangka karang. Fenomena ini dikenal dengan pemutihan karang (coral bleaching) (Burke et al., 2012).

Pemanfaatan citra satelit untuk menduga SPL dapat digunakan untuk menganalisis potensi terjadinya pemutihan karang (Liu et al., 2014; Strong., 2011). Saat ini National Ocean Atmospheric Administrations (NOAA) melalui program Coral Reef Watch (CRW) telah memproduksi peta potensi pemutihan karang yang disebut dengan Hotspot (HS). HS adalah Algoritma yang dikembangkan oleh CRW dengan menghitung selisih antara SPL terhadap SPL rata-rata bulanan tertinggi (maximum mean monthly) (SPL MMM) (Liu et al., 2014). Lamanya sebuah HS mendiami suatu perairan diketahui dengan nilai Degree HeatingWeek (DHW). DHW juga disebut sebagai indeks pemutihan karang dan digunakan untuk mengungkapkan kejadian pemutihan (Liu et al., 2014). Nilai HS dan
DHW inilah yang digunakan dalam memetakan potensi pemutihan karang (Liu et al., 2014; Strong et al. ,2011; Eakin., 2010 ).

Produk HS dan DHW CRW Memiliki resolusi spasial $50 \mathrm{~km}$. Resolusi ini kurang baik digunakan di area yang tidak terlalu luas dan terumbu karang yang berada pada morfologi pantai yang komplek seperti di perairan Bali. Oleh karena itu diperlukan citra satelit dengan resolusi yang lebih tinggi untuk memberikan informasi yang lebih baik. Salah satu citra satelit yang dapat digunakan adalah Moderate Resolution Imaging Spectroradiometer (MODIS) dengan resolusi spasial $1 \mathrm{~km}$.

Resolusi SPL yang lebih tinggi diperlukan dalam memantau HS dan DHW terumbu karang di perairan Bali. Perairan Bali memiliki terumbu karang yang luas dan tersebar hampir diseluruh perairan Bali. Lokasi terumbu karang tersebar mulai dari bagian barat meliputi Taman nasional Bali Barat (TNBB), bagian utara, Tulamben, Desa Les, Pemuteran. Bagian timur terumbu karang Nusa Penida, Amed, Jemeluk Karangasem. Di selatan pulau Bali terumbu karang ditemukan di Sanur, Pulau Serangan, Nusa Dua.

Luasnya terumbu karang pulau Bali memerlukan pemantauan yang cepat dan efisien khususnya pemantauan kejadian bleaching terumbu karang. Tahun 2015-2016 merupakan tahun terpanas sepanjang sejarah. Intensitas El Nino20152016 lebih tinggi jika dibandingkan dengan El Nino tahun 1997-1997 (Zhai, 2017). Oleh karena itu, pada penelitian ini dilakukan analisis HS dan DHW pada tahun 2015 sampai 2016 melalui analisis citra MODIS untuk melakukan pendugaan potensi kejadian pemutihan karang di perairan Bali.

\section{Metode Penelitian}

\subsection{Lokasi Penelitian}

Lokasi penelitian terhadap kejadian pemutihan karang menggunakan data satelit dilakukan pada wilayah perairan Bali (Gambar 1). Akurasi perhitungan HS dan DHW yang digunakan sebagai indikator pemutihan karang dibandingkan dengan data observasi lapangan yang didapatkan dari Coral Triangel Center (CTC) dan CRW. Sebaran lokasi observasi pemutihan karang berjumlah 6 lokasi pada wilayah perairan Nusa Penida dan Tulamben seperti terlihat pada Table 1.

\subsection{Data Satelit}




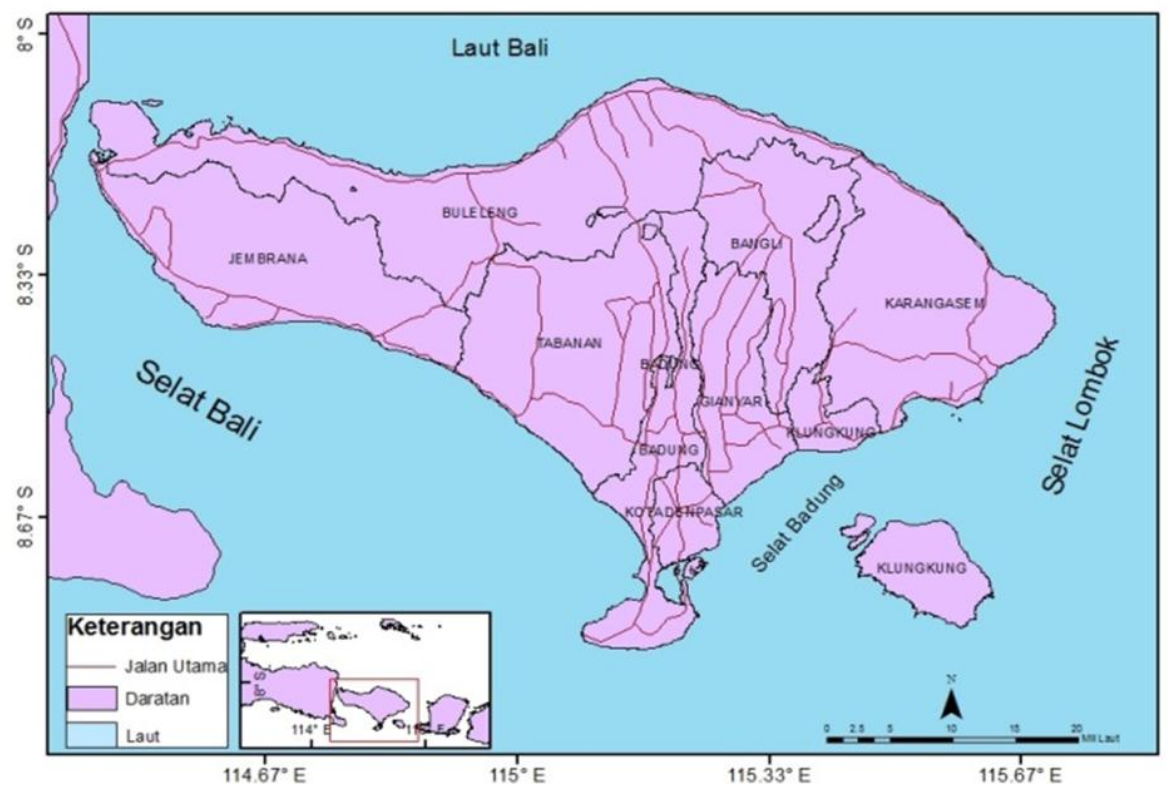

Gambar 2. Lokasi Penelitian

Tabel 1

Lokasi observasi lapangan

\begin{tabular}{|c|c|c|c|c|}
\hline No & Lokasi & Kordinat & Tanggal & sumber \\
\hline 1 & Bali Hai, Nusa Lembongan & S -8.67806 $;$ E $115.4319^{\circ}$ & 1 Maret 2016 & CTC \\
\hline 2 & Mangrove, Nusa Lembongan & S-8.66332 $;$ E115.4669 & 3 Juni 2016 & CTC \\
\hline 3 & Suana, Nusa Penida & S -8.72430; E115.5970 & 3 Juni 2016 & CTC \\
\hline 4 & Buyuk, Nusa penida & S -8.67301; E115.5475º & 3 Juni 2016 & CTC \\
\hline 5 & Kristal Bay & S -8.71528; E $115.4567^{\circ}$ & 4 Juni 2016 & СТC \\
\hline 6 & Tulamben, Karangasem & S -8.27604 ; E $115.5932^{\circ}$ & 24 Juni 2015 & coralwatch \\
\hline
\end{tabular}

Data satelit yang digunakan adalah Aqua MODIS level 2 dengan resolusi spasial $1 \mathrm{~km}$ dan merupakan data harian dari tahun 2005 - 2016. Data SPL diunduh dari situs ocean colour yaituhttp://www.oceancolor.gsfc.nasa.gov. Data SST Level 2 merupakan data yang belum dikoreksi geometric dan belum dilakukan masking awan.

\subsubsection{Metode Pengolahan SST}

Dalam penelitian ini digunakan data SPL malam hari, agar efek silau matahari (sun glare) dapat ditiadakan dan variabilitas suhu akibat pemanasan di siang hari berkurang (Strong et al., 2011).

Pengolahan citra modis level 2 dilakukan dengan menggunakan software SeaDas 7.3. Koreksi geometrik dilakukan agar data memiliki informasi geografis sehingga data siap digunakan. Untuk mendapatkan citra bulanan dilakukan proses mosaicking, yaitu penggabungan citra harian untuk mendapatkan rata-rata mingguan dan bulanan.

\subsection{Penilaian status pemutihan karang}

Untuk melakukan perhitungan HS, maka sebelumnya harus ditentukan SPL normal. SPL normal adalah SPL rata-rata bulanan tertinggi (MMM) (Eladawy et al., 2015; Liu et al., 2014; Strong et al., 2011;). Pada penelitian ini SPL normal dihitung selama 11 tahun, yaitu data dari tahun 2005-2016. HS pada penelitian ini dihitung dengan persamaan 1 (Liu et al., 2014).

$\mathrm{HS}=\left\{\begin{array}{l}\mathrm{HS}, \mathrm{SPL}-\mathrm{MMM}, \mathrm{SPL} \text { mingguan }>\mathrm{MMM} \\ 0, \quad \text { SPL mingguan } \leq \mathrm{MMM}\end{array}\right.$

Hanya Nilai HS positif lebih dari 1 (MMM+1) yang digunakan untuk menggambarkan kejadian pemutihan karang (Kayanne, 2017; Liu et al., 2014 Mohanty et al., 2017; Shuail et al., 2016). Selanjutnya, dihitung lama waktu (minggu) HS mendiami suatu perairan yang dinyatakan dalam Degree Heating Week (DHW) dengan satuan derajat celcius-minggu $\left({ }^{\circ} \mathrm{C}\right.$-minggu). DHW dalam suatu 
piksel dapat dihitung sesuai persamaan 2 (Heron et al., 2016; Liu et al., 2014).

$$
\mathrm{DHW}=\sum_{\mathrm{i}=1}^{12}\left(\mathrm{HS}, \mathrm{jika} \mathrm{HS} \geq 1^{\circ} \mathrm{C}\right)
$$

\subsection{Kriteria Penilaian Status Terumbu Karang}

Status pemutihan karang pada lokasi penelitian mengacu pada kriteria yang digunakan oleh Liu et al. (2014) seperti terlihat pada Tabel 2.

Tabel 2.

Status Pemutihan karang

\begin{tabular}{|c|c|c|c|}
\hline $\operatorname{Hotspot}\left({ }^{\circ} \mathrm{C}\right)$ & $\begin{array}{c}\text { Degree of } \\
\text { Heating } \\
\text { Week/DHW } \\
\left({ }^{\circ} \mathrm{C} \text {. Week }\right)\end{array}$ & Alert Status & Effect \\
\hline$H S: \leq 0$ & - & No Stress & - \\
\hline HS: $0-1$ & - & Watch & $\begin{array}{c}\text { Thermal stress } \\
\text { on corals }\end{array}$ \\
\hline \multirow[t]{3}{*}{$H S: 1 \geq H S$} & $0 \geq D H W \leq 4$ & Warning & $\begin{array}{c}\text { Possible } \\
\text { Bleaching }\end{array}$ \\
\hline & $4>D H W \leq 8$ & Alert Level 1 & $\begin{array}{l}\text { Bleaching } \\
\text { Likely }\end{array}$ \\
\hline & $8>D H W$ & Alert Level 2 & MortalityLikely \\
\hline
\end{tabular}

\subsection{Analisa Data}

\subsubsection{Spasial}

Analisa sebaran DHW secara spasial dengan melihat degradasi warna yang menunjukan perbedaan nilai DHW pada setiap pikselnya. Software yang digunakan untuk membantu pengolahan data spasial DHW yaitu SAGA GIS. Analisa distribusi spasial yang ditampilkan berupa peta analisis HS dan DHW pada tahun 2015-2016.

\subsubsection{Analisa Temporal}

Analisa temporal SPL dilakukan berdasar grafik time series untuk mendapatkan kondisi normal hasil rerata SPL bulanan 2015 - 2016. Dalam analisis temporal HS dan DHW diolah berupa grafik yang gunanya untuk mengetahui sebaran HSdan DHW berdasarkan perbedaan waktu.

\section{Hasil dan Pembahasan}

\subsection{SPL}

Fluktuasi SPL bulanan di perairan Bali dapat dilihat pada Gambar 2. Grafik fluktuasi SPL tersebut menunjukan SPL di tahun 2015 mengalami penurunan pada bulan April-September 2015. Penurunan SPL di perairan Bali pada bulan-bulan tersebut dapat berhubungan dengan upwelling, dimana Samudera Hindia bagian timur meliputi perairan selatan jawa, perairan pulau Bali sampai Nusa Tenggara merupakan daerah upwelling yang sangat intensif (Sprintall et al., 2010). Raditya et al. (2013), Yuhendrasmiko et al. (2016), Wisha et al. (2016) menunjukkan terjadinya penurunan SPL di sepanjang pesisir Sumatera, Jawa sampai dengan Nusa Tenggara pada bulan Juni - Oktober yang diakibatkan oleh peristiwa upwelling. Pada penelitian ini penurunan SPL terendah terjadi pada bulan September 2015 mencapai $25.71^{\circ} \mathrm{C}$.

Fluktuasi SPL pada tahun 2016 tidak seperti pada tahun 2015. SPL terendah tahun 2016 sebesar $27.55^{\circ} \mathrm{C}$ yang terjadi pada bulan Agustus. SPL terendah di tahun 2016 lebih tinggi dari SPL terendah tahun 2015.

Fluktuasi SPL pada Gambar 2 menunjukan kenaikan SPL mulai terjadi pada bulan Oktober 2015 dan terus mengalami peningkatan sampai dengan puncaknya terjadi pada bulan Maret 2016 sebesar $30,19^{\circ} \mathrm{C}$. SPL rata-rata di wilayah perairan Bali pada tahun 2015 sebesar $27,49^{\circ} \mathrm{C}$, sementara pada tahun 2016 sebesar $28,97^{\circ} \mathrm{C}$. Data tersebut menunjukkan terjadinya peningkatan SPL rata-rata pada tahun 2015 dan tahun 2016 sebesar 1,48 $\mathrm{C}$.

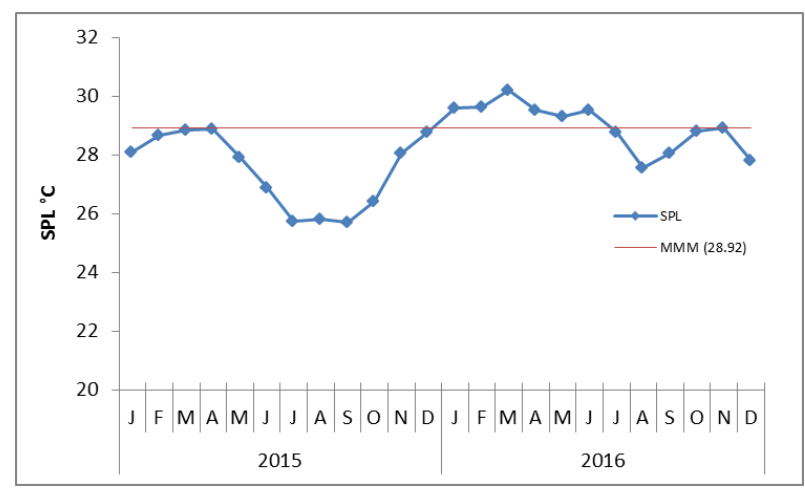

Gambar 2. SPL Perairan Bali tahun 2015-2016

SPL normal/MMM ditunjukkan pada Gambar 2. Melalui data satelit Aqua MODIS didapatkan MMM rata-rata di wilayah perairan Bali sebesar $28,92^{\circ} \mathrm{C}$. SPL di perairan Bali terlihat melebihi MMM pada bulan Januari-Juni 2016. SPL diatas MMM mengindikasikan tekanan terhadap ekosistem yang sensitif terhadap SPL, khususnya ekosistem terumbu karang (Teneva et al., 2012). MMM pada suatu wilayah akan memiliki nilai yang berbeda yang mengindikasikan karakteristik yang berbeda (Liu et al,. 2014). 
Variasi musiman SPL dapat dikelompokan berdasarkan pola umum angin di Indonesia, yaitu musim barat terjadi pada Desember, Januari, Februari (DJF); musim peralihan 1 terjadi pada bulan Maret, April, Mei (MAM); Musim timur terjadi pada Juni, Juli, Agustus (JJA); dan musim peralihan 2 terjadi pada September, Oktober, November (SON)(Wyrtki, 1961 in Mulyadi, 2017). SPL ratarata tertnggi di wilayah perairan Bali terjadi pada saat MAM 2016 dengan nilai sebesar 29,18 ${ }^{\circ} \mathrm{C}$, sementara SPL rata-rata terendah terjadi saat JJA 2015 sebesar $26,18^{\circ} \mathrm{C}$. Tinggi rendahnya SPL di wilayah perairan Indonesia pada tiap musimnya dipengaruhi oleh fenomena armondo (arus monsum Indonesia) dan upwelling (Kunarso, 2012).

Gambar 3 ditampilkan grafik rata-rata SPL musiman tahun 2015-2016. Kenaikan SPL juga terjadi pada rata-rata SPL musiman. Rata-rata SPL DJF 2015 sebesar $28.31^{\circ} \mathrm{C}$ dan DJF 2016 sebesar $29.45^{\circ} \mathrm{C}$. SPL DJF 2015-2016 mengalami kenaikan sebesar $1.14^{\circ} \mathrm{C}$. Rata-rata SPL MAM pada tahun 2015 sebesar $28.55^{\circ} \mathrm{C}$ dan $29.8^{\circ} \mathrm{C}$ pada MAM tahun 2016. Selisih MAM tahun 2015 dan 2016 adalah sebesar $1.24^{\circ} \mathrm{C}$. Pada JJA antara tahun 2015-2016 terlihat mengalami kenaikan. SPL Rata-rata JJA tahun 2015 adalah sebesar $26.18^{\circ} \mathrm{C}$ dan $28.12^{\circ} \mathrm{C}$ pada tahun 2016. Selisih SPL JJA antara tahun 2015-2016 sebesar $1.96^{\circ} \mathrm{C}$. Kenaikan rata-rata SPL musiman paling tinggi terjadi pada SON antara tahun 2015-2016. Rata-rata SPL SON 2015 sebesar $26.73^{\circ} \mathrm{C}$ dan $28.75^{\circ} \mathrm{C}$ pada tahun 2016. Selisih SON 2015-2016 adalah $2.02^{\circ} \mathrm{C}$. Perbedaan SPL bulanan dan musiman tahun 2015-2016 menunjukan terjadi selisih $1.48^{\circ} \mathrm{C}$. Strong et al. (2011) menyatakan peningkatan suhu tahunan sebesar $1^{\circ} \mathrm{C}$ dapat menyebabkan terjadinya pemutihan karang.

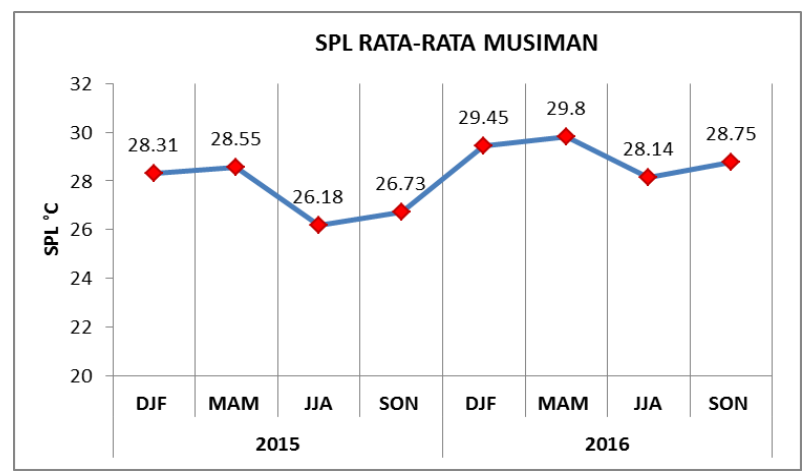

Gambar 3. Rata-rata SPL musiman diperairan Bali.

Gambar 4 menunjukan distribusi SPL secara spasial di perairan Bali. Secara umum SPL di perairan bagian utara Pulau Bali memiliki Suhu yang lebih tinggi dibandingkan perairan selatan Bali. Pada saat JJA dan SON tahun 2015 upwelling dapat terlihat di perairan selatan Bali, utamanya di Selat Bali dan perairan sekitar Selat Badung termasuk Nusa Penida. Namun kejadian yang sama tidak terjadi pada tahun 2016. Menurut Raditya et al. (2013) terjadinya upwelling di samudra hindia bagian timur sepanjang perairan selatan Pulau Jawa sampai Nusa Tenggara yang terjadi di musim timur. Upwelling yang terjadi di Samudra hindia berpengaruh langsung terhadap perairan selatan
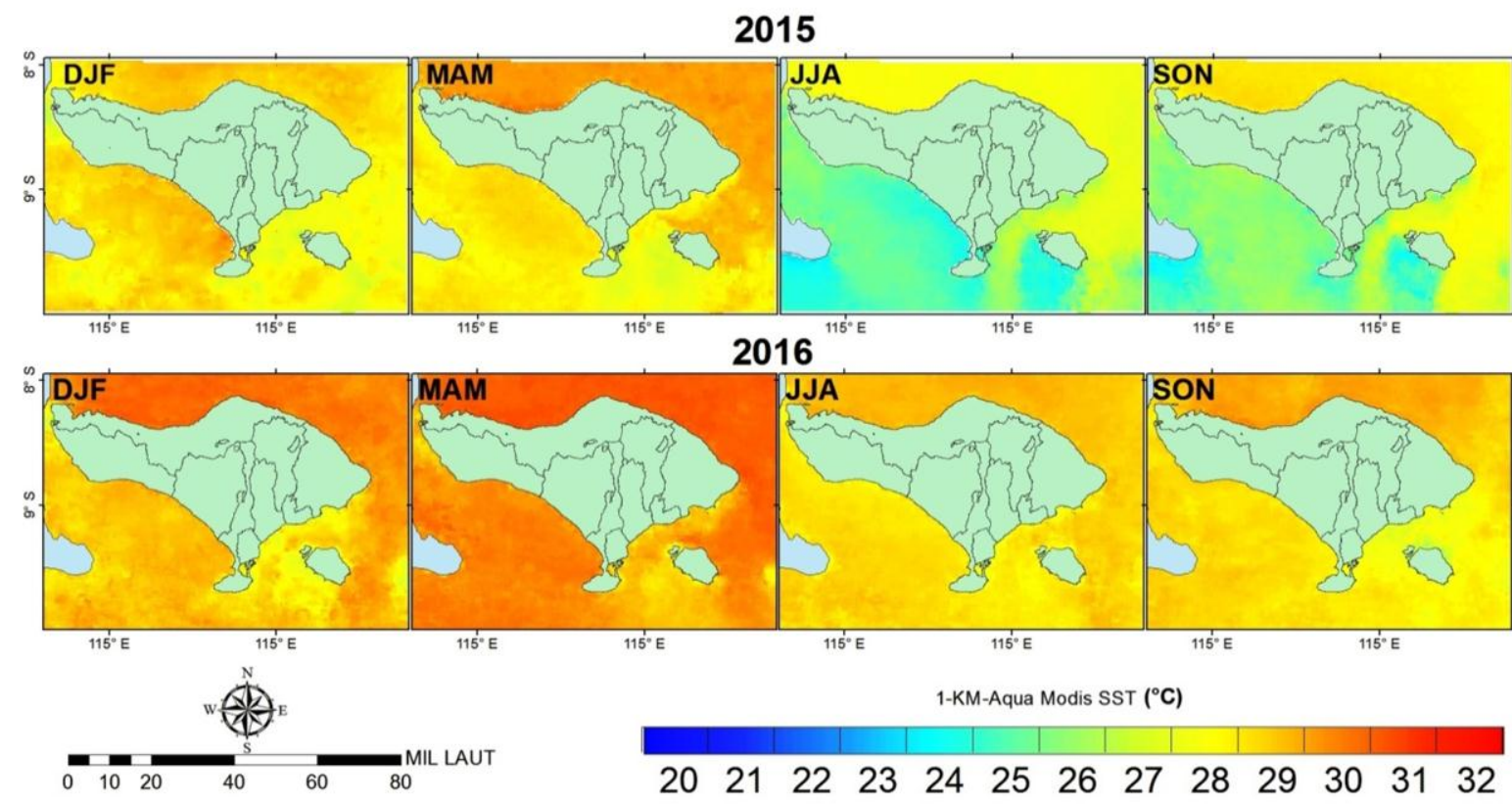

Gambar 4. Sebaran SPL tahun 2015-2016 
Bali mulai dari selat Bali, Selat Badung dan periaran selatan Nusa Penida. Hal ini dapat diindikasikan dengan rendahnya SPL di bagian selatan. Pada saat DJF tahun 2016 rata-rata SPL bagian utara (Laut Bali) lebih tinggi dari selatan begitu juga pada saat MAM.

Adanya fenomena seperti ENSO menjadi faktor lain yang menyebabkan SPL suatu perairan meningkat atau menurun. Penomena ENSO terjadi pada tahun 2015-2016 (Zhai et al., 2016). Fase ENSO pada tahun 2015 adalah El Nino dengan intensitas kuat (McPhaden 2015). Tahun 2016 El Nino melamah dan mulai terjadi fase La Nina (Zhai et al., 2016;). Ketika El Nino terjadi bagian timur Samudra Fasifik memiliki SPL lebih hangat dibandingkan di Indonesia. La Nina merupakan kebalikan El Nino, dimana SPL di timur sampai tengah Pasifik lebih rendah dan SPL di Indonesia lebih tinggi (Ilahude dan Nontji, 1999).

\subsection{Hotspot dan DHW}

Secara temporal, HS rata-rata bulanan tertinggi di wilayah perairan Bali sebesar $1,48^{\circ} \mathrm{C}$ yang terjadi pada bulan Maret 2016 yang ditunjukan Gambar 5. HS pada bulan Maret 2016 di wilayah perairan Bali menunjukkan nilai melebihi $1^{\circ} \mathrm{C}(\mathrm{HS}>1)$, yang memberikan indikasi dapat memberikan dampak stres terhadap ekosistem terumbu karang (Liu et al., 2014; Strong et al., 2011).

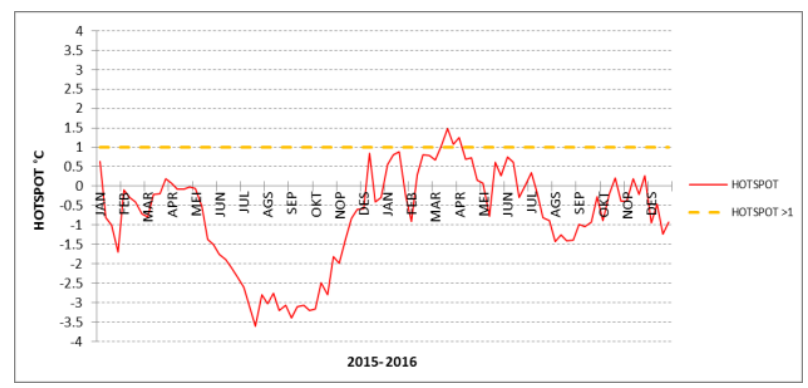

Gambar 5. HS rata-rata di Perairan Bali. Warna merah menunjukan nilai HS .dan garis kuning putusputusadalah batas HS lebih dari 1 .

Lama tinggal HS pada suatu wilayah perairan ditunjukkan dengan nilai DHW. Semakin tinggi nilai DHW menunjukan semakin lama HS $>1$ mendiami suatu perairan. Pada penelitian ini, DHW April 2016 merupakan DHW paling tinggi seperti diperlihatkan pada Gambar 6. DHW bulan April didapatkan dari akumulasi HS yang dimulai dari bulan Januari sampai bulan Maret 2016 (selama tiga bulan sebelumnya). Untuk melihat distribusi spasial DHW rata-rata pada beberapa lokasi terumbu karang yang ada di sekitar perairan Bali tahun 2015 dan 2016 dapat dilihat pada Gambar 7. Lokasi ekosistem terumbu karang yang ada diperairan Bali di peroleh dari Welly et al (2016).

Perairan Bali dibagi menjadi 5 wilayah seperti pada gambar 13. Pembagian wilayah ditunjukan dengan kotak nomor 1 sampai 5. Setiap kotak mewakili pembagian lokasi terumbu karang di periaran Bali.

Lokasi terumbu karang di perairan Bali bagian barat ditunjukan oleh kotak nomor 1. Lokasi terumbu karang di perairan Bali bagian Barat diataranya adalah Taman Nasional Bali Barat (TNBB) dan Pulau Burung Gili Manuk. DHW ratarata spasial saat puncak peningkatan DHW pada Bulan April 2017 di perairan barat Pulau Bali adalah $2.81^{\circ} \mathrm{C}$-minggu, yang artinya perairan tersebut berada pada status watch.

Lokasi terumbu karang di perairan Bali bagian utara ditunjukan oleh kotak nomor 2. Lokasi terumbu karang di perairan Bali bagian Utara diataranya adalah Lovina, Desa Les, Pemaron. DHW rata-rata spasial saat puncak peningkatan DHW pada Bulan April 2017 di perairan barat Pulau Bali adalah $1.56^{\circ} \mathrm{C}$-minggu, yang artinya perairan tersebut berada pada status watch.

Kotak nomor 3 mewakili lokasi terumbu karang di perairan Bali bagian timur. Lokasi terumbu karang di bagian timur perairan Bali diantaranya Jemeluk-Amed, Kepah-Amed, Gili Biaha, Gili Tapekong. DHW rata-rata spasial saat puncak peningkatan DHW pada Bulan April 2017 di perairan barat Pulau Bali adalah $2.68^{\circ} \mathrm{C}$-minggu, yang artinya perairan tersebut berada pada status watch.

Lokasi terumbu karang di perairan Bali bagian tenggara ditunjukan oleh kotak nomor 4. Lokasi terumbu karang di perairan Bali bagian tenggara diataranya adalah Mangrove Point, Crystal Bay, Suwehan dan Ped. DHW rata-rata spasial saat puncak peningkatan DHW pada Bulan April 2017 di perairan barat Pulau Bali adalah $4.65^{\circ} \mathrm{C}$-minggu, yang artinya perairan tersebut berada pada status Alert level 1. Dampak dari Alert level 1 adalah kemungkinan besar akan terjadi pemutihan karang.

Lokasi terumbu karang di perairan Bali bagian selatan ditunjukan oleh kotak nomor 5. Lokasi terumbu karang di perairan Bali bagian selatan diataranya adalah Sanur, Pulau Serangan, Tanjung Benoa, Nusa Dua dan Pantai Melasti. DHW rata- 


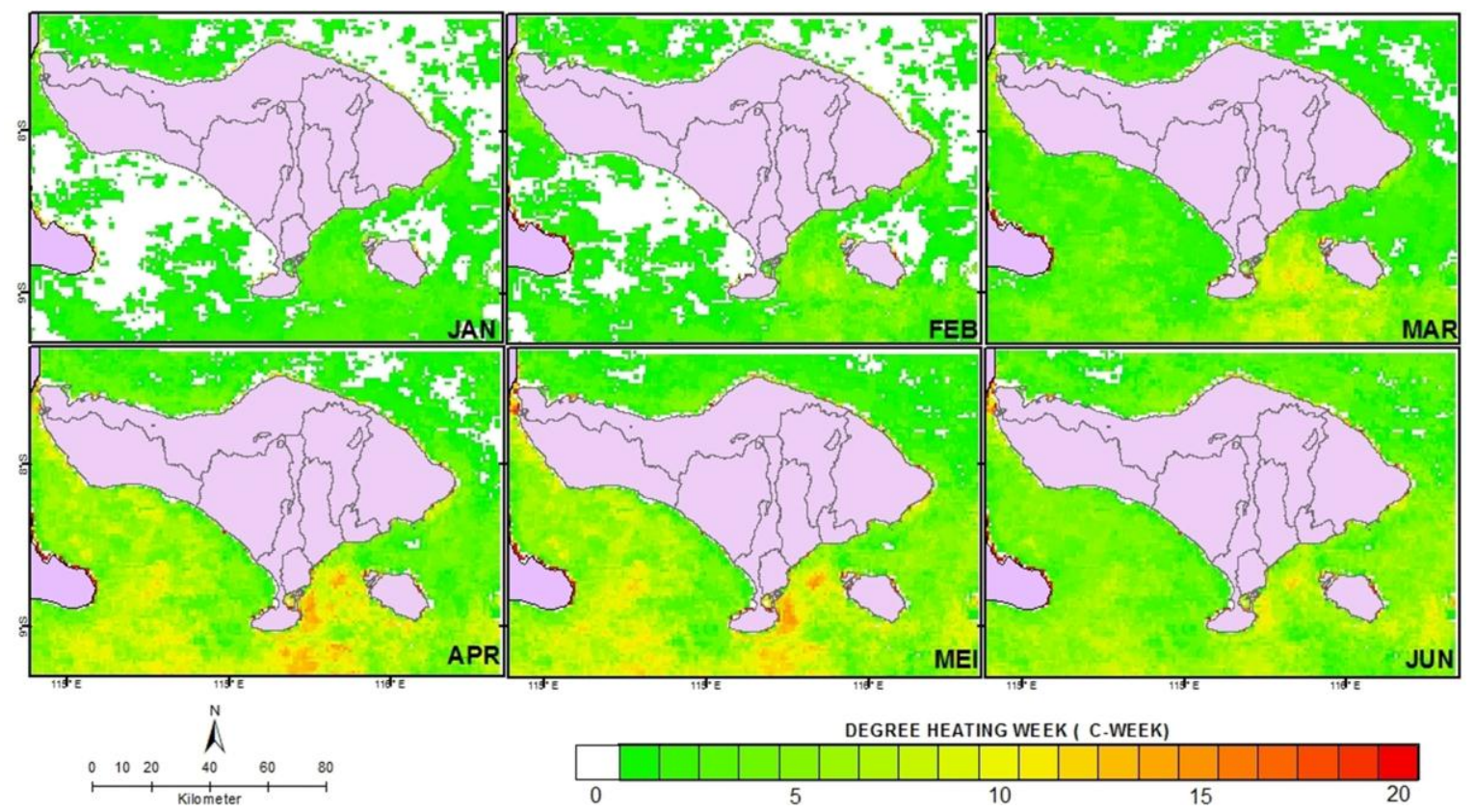

Gambar 6. DHW spasial lokasi penelitian tahun 2016

rata spasial saat puncak peningkatan DHW pada Bulan April 2017 di perairan selatan Pulau Bali adalah $2.89^{\circ} \mathrm{C}$-minggu, yang artinya perairan tersebut berada pada status watch.

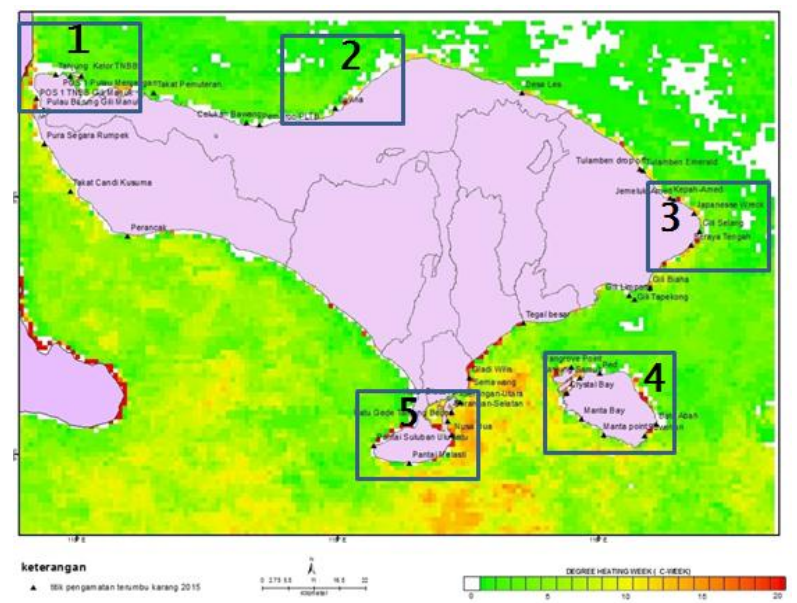

Gambar 7. Lokasi terumbu karang dengan DHW pada bulan april 2016. Penomoran Kotak mewakili sebaran DHW secara Spasial di perairan Bali.nomor 1 (barat), nomor 2 (utara), nomor 3 (timur), nomor 4 (tenggara) ,nomor 5 (selatan).

Berdasarkan nilai DHW rata-rata spasial, perairan Bali bagian tenggara (perairan Nusa Penida) memiliki rata-rata DHW paling tinggi yaitu $4.65^{\circ} \mathrm{C}$-minggu (Alert level 1, efek terjadi pemutihan). Sebaran spasial DHW di perairan Nusa Penida memperlihatkan DHW di bagian barat Pulau Nusa Penida lebih tinggi dibandingkan bagian timur Nusa Penida. Hal ini disebabkan dibagian timur Nusa Penida banyak terjadi upwelling. Hendrawan dan Asai (2011) Menunjukan mekanisme upwelling di bagian timur pulau nusa penida akibat keberadaan Lombok sill, sehingga SPL diwilayah tersebut menjadi lebih rendah dibandingkan daerah lainnya di Nusa Penida.

Sebaran spasial DHW di perairan Nusa Penida memperlihatkan DHW di bagian barat Pulau Nusa Penida lebih tinggi dibandingkan bagian timur Nusa Penida. Hal ini disebabkan dibagian timur Nusa Penida banyak terjadi upwelling. Hendrawan and Asai (2011) Menunjukkan mekanisme upwelling di bagian timur pulau nusa penida akibat keberadaan Lombok sill, sehingga SPL diwilayah tersebut menjadi lebih rendah dibandingkan daerah lainnya di Nusa Penida.

\subsection{Perbandingan DHW NOAA CRW}

Untuk melihat pola kesesuaian DHW antara produk CRW dengan resolusi spasial $50 \mathrm{~km}$ dengan DHW pada penelitian ini dengan resolusi $1 \mathrm{~km}$, maka dilakukan perbandingan hasil seperti terlihat pada gambar 8. Pola DHW CRW dengan DHW pada penelitian ini menunjukkan pola yang sama dengan korelasi rata-rata sebesar 0.91. DHW CRW dengan resolusi spasial $50 \mathrm{~km}$ tidak dapat memberikan informasi secara detail pada wilayah perairan Bali. Namun dengan menggunakan DHW 
pada penelitian ini telah dapat memberikan informasi yang lebih detail terhadap kondisi terumbu karang di beberapa tempat diwilayah perairan Bali.

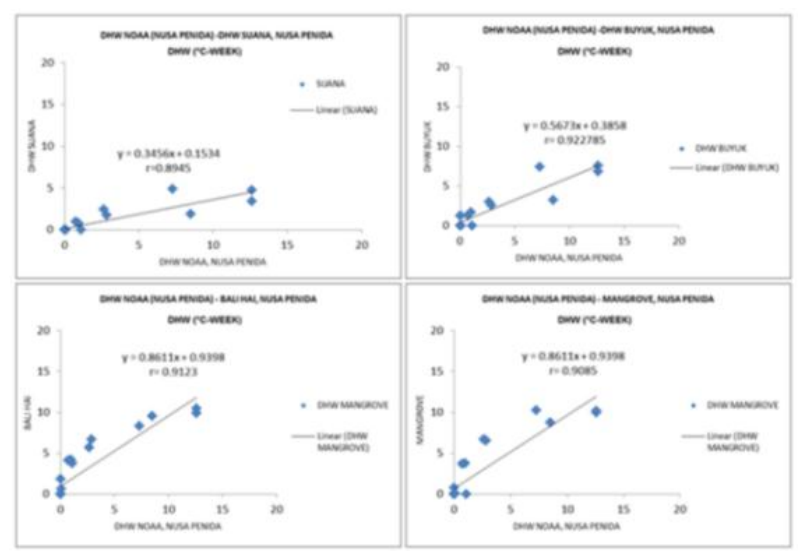

Gambar. 8. Nilai korelasi DHW MODIS dengan CRW di perairan Nusa Penida.

Dalam memantau HS dan DHW diberbagai tempat, NOAA CRW membuat virtual Station.Salah satu virtual station NOAA berada di periran Nusa Penida menunjukan hasil perekaman DHW tertinggi adalah $12.62{ }^{\circ} \mathrm{C}$-minggu yaitu pada bulan Mei 2016. Berdasarkan Tabel 1 perairan dengan DHW diatas $8^{\circ} \mathrm{C}$-minggu seharusnya menyebabkan terumbu karang mengalami kematian. Akan tetapi hal ini tidak terjadi di semua lokasi di perairan Nusa Penida. Hasil survey CTC di perairan Nusa Penida tahun 2016 menyebutkan, ditemukan pemutihan terumbu karang 13-35\% dan kematian terumbu karang hanya di temukan di lokasi 1 (Bali Hai) dengan kematian terumbu karang $7 \%$ dari $44 \%$ rata-rata tutupan karang.

Kesamaan pola DHW NOAA CRW dengan DHW MODIS diperlihatkan secara temporal pada Gambar 9.DHW NOAA CRW maupun DHW Pada penelitian ini mengalami kenaikan mulai bulan Januari 2016 sampai dengan bulan Juni 2016.Secara umum DHW CRW dan MODIS mengalami peningkatan pada tahun 2016.Terjadinya peningkatan DHW pada tahun 2016 di perairan Bali dapat menjadikan indikator pemutihan karang di beberapa wilayah di perairan Bali.Dalam penelitian ini lokasi survei pemutihan karang berada di periaran nusa Penida.

\subsection{Kondisi DHW dan pemutihan Karang di beberapa lokasi di wilayah perairan Bali}

Tabel 3 menunjukkan kejadian pemutihan karang/kematian karang hasil observasi lapangan di beberapa lokasi di wilayah perairan Bali dan hubungannya dengan DHW dan SPL. Lokasi pemutihan karang diantanya Bali Hai , Buyuk, Terumbu karang di lokasi mangrove, Suana, Kristal Bay berada di perairan nusa Penida. Sedangkan lokasi lain adalah Tulamben yang ada di periaran timur bali( karangasem). Terumbu karang yang berlokasi di Bali Hai berada di Kawasan Konservasi Nusa Penida, pamantauan pemutihan karang yang dilakukan oleh CTC pada tanggal 1 Maret 2016 menunjukkan bahwa telah terjadi pemutihan karang di wilayah tersebut sebesar 30\% dengan kematian karang $7 \%$. Pada saat yang sama

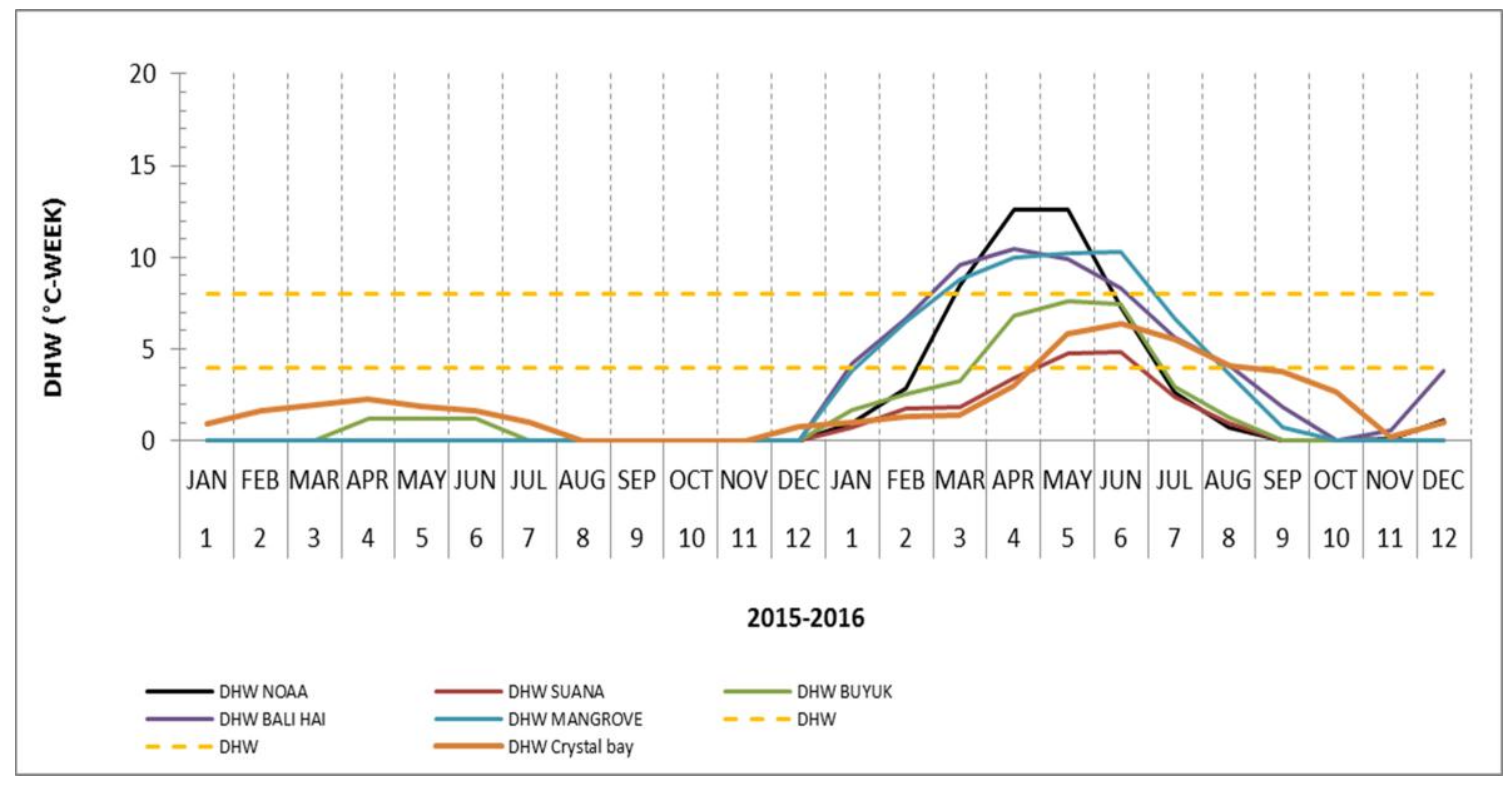

Gambar 9. DHW MODIS dengan DHW NOAA CRW 
Tabel 3

Hasil survey untuk kawasan Nusa Penida. Data yang ditampilkan merupakan data hasil survey CTC dan data yang diperoleh dari coralwatch.org

\begin{tabular}{|c|c|c|c|c|c|c|c|c|}
\hline No & Lokasi & Tanggal & $\begin{array}{l}\text { Suhu } \\
\left({ }^{\circ} \mathrm{C}\right)\end{array}$ & $\begin{array}{c}\text { DHW } \\
\left({ }^{\circ} \mathrm{C} \text {-week) }\right.\end{array}$ & MMM & $\begin{array}{c}\text { Kejadian } \\
\text { Bleaching } \\
(\%)\end{array}$ & Jenis Karang & $\begin{array}{c}\text { Karang } \\
\text { Mati (\%) }\end{array}$ \\
\hline 1 & $\begin{array}{l}\text { KKP / Bali Hai, Lem- } \\
\text { bongan Bay }\end{array}$ & 1 Maret 2016 & - & 8.96 & 28.32 & $30 \%$ & Porites (masiv) & $7 \%$ \\
\hline 2 & Mangrove & 3 Juni 2016 & 25 & 9.88 & 28.53 & $13 \%$ & & \\
\hline 3 & Sauna & 3 Juni 2016 & 29 & 6.57 & 29.01 & $35 \%$ & $\begin{array}{l}\text { Hydnophora, Porites, Echinopora, } \\
\text { Montipora, Acropora (tabulate, } \\
\text { branching, submassive), Merulina, } \\
\text { Pachyseris, Poccilopora, Pectinia, } \\
\text { Gardineroseris, Diploastrea. }\end{array}$ & \\
\hline 4 & Bunyuk & 3 Juni 2016 & 29 & 8.79 & 28.81 & $35 \%$ & $\begin{array}{l}\text { Hydnophora, Porites, Echinopora, } \\
\text { Montipora, Acropora (tabulate, } \\
\text { branching, submassive), Merulina, } \\
\text { Pachyseris, Poccilopora, Pectinia, } \\
\text { Gardineroseris, Diploastrea. }\end{array}$ & \\
\hline 5 & Crystal Bay & 4 Juni 2016 & - & 6.65 & 28.20 & - & - & - \\
\hline 6 & Tulamben & 24 Juni 2015 & 28 & 1.11 & 29.40 & $41.5 \%$ & Karang tipe branching. & \\
\hline
\end{tabular}

dalam penelitian ini SPL rata-rata dan DHW dilokasi tersebut didapatkan berturut-turut sebesar $27,8^{\circ} \mathrm{C}$ dan $8,97^{\circ} \mathrm{C}$-minggu. Jika merujuk pada kategori status pemutihan karang, maka terumbu karang di perairan Bali Hai termasuk dalam status Alert 2(mortality likely). Status Alert 2 di Bali Hai menunjukkan terumbu karang di perairan tersebut telah terjadi pemutihan karang dan kemungkinan akan terjadi kematian karang. Hasil ini memiliki kesesuaian dengan data lapangan yang dilaporkan oleh CTC.

Terumbu karang dilokasi mangrove Nusa Lembongan berada di bagian timur tenggara pulau Nusa Lembongan. Dari penelitian ini didapatkan DHW di lokasi mangrove Nusa Lembongan sebesar $9.88^{\circ} \mathrm{C}$-minggu. Survei lapangan oleh CTC dilakukan pada 3 juni 2016. Nilai DHW di lokasi ini termasuk kategori Alert Level 2 dengan efek yang ditimbulkan yaitu kematian terhadap terumbu karang (mortality likely). di lokasi ini terjadi pemutihan karang sebesar 13\% namun tidak ditemukan kematian karang dilokasi tersebut.

Lokasi terumbu karang Suana berada di sebelah Timur Pulau Nusa Penida. DHW dilokasi tersebut didapatkan sebesar $7.7^{\circ} \mathrm{C}$-minggu. DHW pada lokasi ini disesuaikan dengan waktu survei lapangan yaitu pada tanggal 5 Juni 2017. Ditemukan pemutihan karang sebesar 30\% dari total tutupan substrat bentik. Dilihat dari nilai
DHW maka status kondisi terumbu karang di lokasi ini adalah Alert Level 1 dan dampaknya adalah bleaching likely. Data lapangan tersebut menunjukan kesesuaian dengan DHW yang didapatkan.

Lokasi terumbu karang Buyuk berada di bagian utara pulau Nusa Penida. DHW pada saat survey adalah $8.7^{\circ} \mathrm{C}$-minggu (Alert Level 2). Menurut nilai DHW dampak yang terjadi adalah kematian pada karang (mortality likely). Sebanyak 35\% terumbu karang dilokasi mengalami bleaching dari 20.7\% total tutupan substrat bentik) pada kedalaman 3 m. (CTC, 2016).

Lokasi terumbu karang Tulamben berada di Kabupaten Karangasem. DHW di Tulamben adalah $1.11^{\circ} \mathrm{C}$-minggu. Survey yang dilakukan pada lokasi ini yaitu pada tanggal 24 Juni 2015. Hasil data lapangan $41.5 \%$ terumbu karang tipe brancing di Tulamben memucat (coralwatch.org). Meskipun pada tahun 2015 DHW di lokasi ini kecil (DHW $<4^{\circ} \mathrm{C}$-week), diduga pemucatan yang terjadi pada lokasi ini diakibatkan karena penurunan SPL pada tahun 2015. Hal tersebut merujuk kepada penelitian Eghbert et al., (2017) yang menyebabkan terumbu karang yang mengalami bleaching pada tahun 2015 disebabkan karena SPL yang menurun.

Dari lokasi terumbu karang yang telah disurvei hanya di lokasi Kristal bay yang tidak timukan pemutihan karang. DHW di Kristal Bay sebesar $6.65^{\circ} \mathrm{C}$-minggu. Survei oleh CTC dilokasi ini dil- 
akukan pada 4 juni 2016. Rangkuman hasil data penelitian pada setiap lokasi ditampilkan pada Tabel 3.

\section{Simpulan}

Data satelit MODIS level 2 dapat digunakan dalam menentukan HS dan DHW. Data satelit Modis level 2 dengan resolusi spasial $1 \mathrm{~km}$ memberikan informasi HS dan DHW yang lebih detail dibandingkan dengan HS dan DHW CRW NOAA. DHW MODIS level 2 menunjukan pola yang sama dengan DHW CRW NOAA. Pola HS dan DHW di wilayah perairan pulau Bali mengalami kenaikan dari tahun 2015-2016. Peningkatan tertinggi terjadi mulai bulan Maret sampai bulan Juni tahun 2016.Status pemutihan pada wilayah perairan Bali berada pada status Alert 1 dan Alert 2.

\section{Ucapan Terima Kasih}

Penulis mengucapkan terima kasih kepada Beasiswa Bidik Misi yang telah memberikan biaya studi. Pembimbing dan penguji yang telah memberikan arahan dan masukan, kritik dan saran.

\section{Daftar Pustaka}

Burke, L., Selig, E., \& Spalding, M. (2002). Terumbu karang yang terancam di Asia Tenggara (ringkasan untuk Indonesia). Washington DC, USA: World Resources Institute.

Coral watch (2016). Bleaching Map. [online] Tersedia di: https://coralwatch.org/web/guest/bleaching-map, [diakses: 15 September 2017].

CTC. (2016). Laporan Bleaching Nusa Penida 2016. Denpasar, Indonesia: Coral Triangle Centre.

Eakin, C. M., Morgan, J. A., Heron, S. F., Smith, T. B., Liu, G., Alvarez-Filip, L., Baca, B., Bartels, E., Bastidas, C., Bouchon, C., Brandt, M., Bruckner, A. W., Bunkley-Williams, L., Cameron, A., Causey, B. D., Chiappone, M., Christensen, T. R. L., Crabbe, M. J. C., Day, O., de la Guardia, E., Diaz-Pulido, G., DiResta, D., Gil-Agudelo, D. L., Gilliam, D. S., Ginsburg, R. N., Gore, S., Guzman, H. M., Hendee, J. C., HernandezDelgado, E. A., Husain, E., Jeffrey, C. F. G., Jones, R. J., Jordan-Dahlgren, E., Kaufman, L. S., Kline, D. I., Kramer, P. A., Lang, J. C., Lirman, D., Mallela, J., Manfrino, C., Marechal, J. P., Marks, K., Mihaly, J., Miller, W. J., Mueller, E. M., Muller, E. M., Toro, C. A. O., Oxenford, H. A., Ponce-Taylor, D., Quinn, N., Ritchie, K. B., Rodriguez, S., Ramirez, A. R., Romano, S., Samhouri, J. F., Sanchez, J. A., Schmahl, G. P., Shank, B. V., Skirving, W. J., Steiner, S. C. C., Villamizar, E., Walsh, S. M., Walter, C., Weil, E., Williams, E.
H., Roberson, K. W., \& Yusuf, Y. (2010). Caribbean Corals in Crisis: Record Thermal Stress, Bleaching, and Mortality in 2005. Plos One, 5(11), e13969.

Eghbert, E. A., Johan, O., Menkes, C. E., Niño, F., Birol, F., Ouillon, S., \& Andréfouët, S. (2017). Coral mortality induced by the 2015-2016 El-Niño in Indonesia: the effect of rapid sea level fall. Biogeosciences, 14(4), 817-826.

Eladawy, A., Nadaoka, K., Negm, A., Saavedra, O. C., \& Hanafy, M. (2015). Assessment of Long Term Thermal Stress on Egyptian Coral Reefs Based on Remotely Sensed Sea Surface Temperature Data. International Journal of Environmental Science and Development, 6(12), 938-946.

Hendrawan, I. G., \& Asai, K. (2011). Numerical Study of tidal upwelling over the sill in the Lombok Strait (Indonesia). In Proceedings of the 21th International Offshore and Polar Engineering Conference. Maui, Hawaii, USA, 19-24 juni 2011 (pp. 494-596).

Heron, S.F., Johnston, L., Liu, G., Geiger, E.F., Maynard, J.A., De La Cour, J.L., Johnson, S., Okano, R., Benavente, D., Burgess, T.F.R., Iguel, J., Perez, D.I., Skirving, W.J., Strong, A.E., Tirak, K., \& Eakin, C.M. (2016). Validation of reef-scale thermal stress satellite products for coral bleaching monitoring. Remote Sensing, 8(1), 59.

Ilahude, A. G., \& Nontji, A. (1999). Oseanografi Indonesia dan perubahan iklim global (El Nino dan La Nina). Dalam Makalah Lokakarya "Kita dan Perubahan iklim Global: Kasus El Nino - La Nina". Jakarta, Indonesia, 18-19 Mei 1999.

Kayanne, H. (2017). Validation of degree heating weeks as a coral bleaching index in the northwestern Pacific. Coral Reefs, 36(1), 63-70.

Kunarso, K., Hadi, S., Ningsih, N. S., \& Baskoro, M. S. (2012). Variabilitas suhu dan klorofil-a di daerah upwelling pada variasi kejadian ENSO dan IOD di perairan selatan Jawa sampai Timor. ILMU KELAUTAN: Indonesian Journal of Marine Sciences, 16(3), 171180.

Liu, G., Heron, S. F., Eakin, C. M., Muller-Karger, F. E., Vega-Rodriguez, M., Guild, L. S., de la Cour, J. L., Geiger, E. F., Skirving, W. J., Burgess, T. F. R., Strong, A. E., Harris, A., Maturi, E., Ignatov, A., Sapper, J., Li, J., \& Lynds, S. (2014). Reef-scale thermal stress monitoring of coral ecosystems: new $5-\mathrm{km}$ global products from NOAA Coral Reef Watch. Remote Sensing, 6(11), 11579-11606.

McPhaden, M. J. (2015). Playing hide and seek with El Niño. Nature Climate Change, 5(9), 791-795.

Mohanty, P. C., Venkateshwaran, P., Mahendra, R. S., Kumar, H. S., Kumar, T. S., Vinithkumar, N. V., Kirubagaran, R., Ramesh, S., Ramesh, R., Sathianarayanan, D., Prakash, V. D., Ramadasss, G. A., \& Shenoi, S. S. C. (2017). Coral Bleaching Along Andaman Coast Due to Thermal Stress During Summer 
Months of 2016: A Geospatial Assessment. American Journal of Environmental Protection, 6(1), 1-6.

Raditya, F. D., Ismunarti, D. H., \& Handoyo, G. (2013). Analisis Prakiraan Luasan Daerah Upwelling di Perairan Selatan Jawa Timur Hingga Selatan Lombok Kaitannya Dengan Hasil Perikanan Tangkap. Journal of Oceanography, 2(1), 111-127.

Shuail, D., Wiedenmann, J., D'angelo, C., Baird, A. H., Pratchett, M. S., Riegl, B., Burt, J. A., Petrov, P., \& Amos, C. (2016). Local bleaching thresholds established by remote sensing techniques vary among reefs with deviating bleaching patterns during the 2012 event in the Arabian/Persian Gulf. Marine pollution bulletin, 105(2), 654-659.

Sprintall, J., Wijffels, S., Molcard, R., \& Jaya, I. (2010). Direct evidence of the south Java current system in Ombai Strait. Dynamics of atmospheres and oceans, 50(2), 140-156.

Strong, A. E., Liu, G., Skirving, W., \& Eakin, C. M. (2011). NOAA's Coral Reef Watch program from satellite observations. Annals of GIS, 17(2), 83-92.

Teneva, L., Karnauskas, M., Logan, C. A., Bianucci, L., Currie, J. C., \& Kleypas, J. A. (2012). Predicting coral bleaching hotspots: the role of regional variability in thermal stress and potential adaptation rates. Coral Reefs, 31(1), 1-12.
Welly, M., Lazuardi, M.E., Sanjaya, W., Prasetya, D., \& Hendrawan, G. (2016). Kondisi biofisik dan sosial ekonomi Pesisir Bali-2015. Denpasar, Indonesia: Pemerintah Provinsi Bali dan The Nature Conservancy.

Wisha, U. J., Al Tanto, T., \& Ilham, I. (2017). Spatial Distribution of Sea Surface Temperature In West Sumatera Seawaters Associated with Indian Ocean Dipole (IOD) Event In Transitional Seasons (AugustOctober) (Case Study: Pasumpahan and Sibonta Island). Jurnal Ilmiah Geomatika, 22(1), 21-28.

Mulyadi, A. (2017). Analisis Spasial dan Temporal Sebaran Suhu Permukaan Laut di Perairan Sumatera Baat. Dinamika Lingkungan, 4(1), 65-74.

Yudasmara, G. A. (2015). Analisis Keanekaragaman dan Kemelimpahan Relatif Algae Mikroskopis di berbagai Ekosistem pada Kawasan Intertidal pulau Menjangan Bali Barat. Jurnal Sains dan Teknologi, 4(1), 503-515.

Yuhendrasmiko, R., Kunarso, K., \& Wirasatriya, A. (2016). Identifikasi variabiltas upwelling berdasarkan indikator suhu dan klorofil-a di Selat Lombok. Journal of Oceanography, 5(4), 530-537.

Zhai, P., Yu, R., Guo, Y., Li, Q., Ren, X., Wang, Y., Xu, W., Liu, Y., \& Ding, Y. (2016). The strong El Niño of 2015/16 and its dominant impacts on global and China's climate. Journal of Meteorological Research, 30(3), 283-297.

(C) 2017 by the authors; licensee Udayana University, Indonesia. This article is an open access article distributed under the terms and conditions of the Creative Commons Attribution license (http://creativecommons.org/licenses/by/3.0/). 